\title{
Standardization of Dates of Guava (Psidium guajava L.) Varieties to Air Layering under Southern Rajasthan Condition
}

\author{
Ganesh Chand, D.K. Sarolia* and Suman K. Yadav \\ ${ }^{1}$ Department of Horticulture, RCA, MPUAT, Udaipur, Rajasthan, India \\ ${ }^{2}$ Division of Crop Production, ICAR-CIAH, Bikaner, Rajasthan, India \\ *Corresponding author
}

\section{A B S T R A C T}

\section{Ke ywords \\ Guava, Air layering, Rooting and variety \\ Article Info \\ Accepted: 10 March 2018 Available Online: 10 April 2018}

This study was carried out to evaluate suitable dates (weeks) of air layering in guava under sub humid southern plains of Rajasthan conditions. Layering was done from 15 June to 5 July on 2 variety i.e. Lalit and shweta. Among the both variety maximum success in terms of early root initiation (July $1^{\text {st }}$ and July $2^{\text {nd }}$ week), higher rooting in layers (June $4^{\text {th }}$ and July $2^{\text {nd }}$ week), number of secondary roots (July $1^{\text {st }}$ week), length of longest root (July $1^{\text {st }}$ and June $4^{\text {th }}$ week) in both the varieties i.e. Lalit and Shweta observed, respectively.

\section{Introduction}

Guava (Psidium guajava L.) belongs to family Myrtaceae and is native to tropical America. It is introduced in India in an early part of seventeenth century (Singh, 1969). The fruit is liked equally by rich as well as poor people due to low price than other fruits, nourishing value, good taste and it is one of the most common fruit in India widely grown all over the tropics and sub-tropics.

Thus, it is popularly known as the apple of tropics. Guava has been cultivated in India since early times and gradually became a crop of commercial significance as it is quite hardy, prolific bearer and highly remunerative even without much care.
This crop also nutritionally rich in vitamin $\mathrm{C}$ (228 $\mathrm{mg}$ per $100 \mathrm{~g}$ ), soluble dietary fiber (5.4 $\mathrm{g}$ per $100 \mathrm{~g})$ and pectin $(0.8 \%)$ and moderate source of pantothanic acid, niacin, vitamin$\mathrm{B}_{6}, \mathrm{E} \& \mathrm{~K}$ as well as minerals like $\mathrm{Ca}, \mathrm{P}, \mathrm{Fe}$, $\mathrm{Mg}, \mathrm{Cu}$ and $\mathrm{Mn}$ (USDA Data Base, 2015). The content of vitamin $\mathrm{C}$ is approximately four times in winter fruits than in rainy season crop (Chundawat et al., 1976).

Guava is a hardy fruit plant and can withstand the diversities of soil and climatic condition. Like other fruit crops guava is propagated by seeds and vegetative means. Seed propagated plants start bearing in 6 to 8 years after planting with variation in fruit yield and quality, while vegetative propagating material precocious in bearing ( 3 to 4 years after 
planting) and produce higher and uniform crop (Bose et al., 1986). So, it is necessary to go through the vegetative means of propagation for guava.

\section{Materials and Methods}

The experiment was conducted during June to December in 2015-16 at the Horticulture Farm, Department of Horticulture, Rajasthan College of Agriculture, Udaipur, Rajasthan, which is situated at $24^{0} 34 \mathrm{~N}$ latitude and $73^{0} 42$ E longitudes at an elevation of 585.5 meters above mean sea level with the objective of to evaluate suitable dates (weeks) of air layering in guava. For this, we have conducted an experiment on 2 different varieties namely Lalit and Shweta. During July month 100 air layering were performed on each genotype mother plant of 5-6 years old, with a total of 1500 layers under study and data interpreted in one way analysis of variance. This experiment was conducted in close spacing (2 $\mathrm{x} 1 \mathrm{~m})$ guava plantation unit.

One year old healthy shoots were selected and on each of these selected shoots a ring of bark about 1.5 to $2 \mathrm{~cm}$ width between two nodes was removed carefully by giving two circular cuts with a sharp knife at about 50-60 cm from the tip of the shoots. Then covered with a handful moistened sphagnum moss which had been previously soaked in water for two to three hours. It was then wrapped with a piece of poly ethylene sheet (150 gauges) to hold the moss in position around the operated portion and tied firmly with plastic rope at both the ends. The layers were separated from the plant when roots were visible through the polythene sheet. After detachment of the layers from the plant the wrapped polythene sheet was removed and layers were then treated with COC (copper oxychloride) @ 3 g per litre and planted in polythene bag $(10 \times 15 \mathrm{~cm})$ after shoot pruning. Observations were recorded on days taken for root initiation, percentage of air layers rooted, root characters (number of secondary roots, length of longest root) on weekly intervals.

\section{Results and Discussion}

The data revealed that the varieties had a significant effect on days taken to rooting, per cent of rooting, root characters (number, length). The results obtained in the present investigation are discussed as under.

\section{Days taken for root initiation}

The data revealed (Table 1) that the layering weeks had a significant effect on the days taken for root initiation in both the varieties and the days taken for root initiation was increased with the increasing layering dates. Lalit variety show earliest root initiation i.e. (35.60 days) was recorded when layering operation performed on July $1^{\text {st }}$ week and Similarly, minimum days taken for rooting in Shweta variety was observed on July $2^{\text {nd }}$ week (39.60 days). Maximum days were taken in Lalit variety when layering performed on September $4^{\text {th }}$ week i.e. $(57.80$ days $)$ in Shweta maximum days taken for rooting were observed on $4^{\text {th }}$ week of September $(59.40$ days). Variety Lalit was stroked early rooting over Shweta. It is evident from the data that the root initiation days were decreased with the advancement of weeks for layering.

This might be due to air layering propagation strike roots early when atmosphere humidity remain relatively higher in semi-arid tropics. In present study July treatment was recorded maximum humidity $(78.38 \%)$ compared to other treatments. The present findings are also in close agreement with the findings of Rehman et al., (2013) observed a minimum day to root initiation (37.19) was taken by layer made on $15^{\text {th }}$ May in Olive. Kumar et al., (2007) also observed July was the best month for making layering. 
Table.1 Effect of air layering dates (weeks) on days taken for root initiation and percentage of air layers rooted in guava

\begin{tabular}{|l|l|c|c|c|c|}
\hline S. No. & Weeks of layering & \multicolumn{2}{|c|}{ Days taken for root initiation } & \multicolumn{2}{|c|}{ Percentage of air layers rooted } \\
\cline { 2 - 5 } & & Lalit & Shweta & Lalit & Shweta \\
\hline $\mathbf{1}$ & $\mathrm{T}_{1}\left(\mathrm{June} 2^{\text {nd }}\right)$ & 46.00 & 49.20 & 61.53 & 58.80 \\
\hline $\mathbf{2}$ & $\mathrm{T}_{2}\left(3^{\text {rd }}\right)$ & 44.00 & 49.80 & 67.20 & 65.10 \\
\hline $\mathbf{3}$ & $\mathrm{T}_{3}\left(4^{\text {th }}\right)$ & 44.20 & 45.80 & 71.19 & 68.67 \\
\hline $\mathbf{4}$ & $\mathrm{T}_{4}\left(\mathrm{July} 1^{\mathrm{st}}\right)$ & 35.60 & 43.40 & 70.77 & 70.14 \\
\hline $\mathbf{5}$ & $\mathrm{T}_{5}\left(2^{\text {nd }}\right)$ & 37.40 & 39.60 & 69.72 & 70.56 \\
\hline $\mathbf{6}$ & $\mathrm{T}_{6}\left(3^{\text {rd }}\right)$ & 36.60 & 40.40 & 67.41 & 69.30 \\
\hline $\mathbf{7}$ & $\mathrm{T}_{7}\left(4^{\text {th }}\right)$ & 38.80 & 42.80 & 66.57 & 66.57 \\
\hline $\mathbf{8}$ & $\mathrm{T}_{8}\left(\mathrm{Aug} 1^{\mathrm{st}}\right)$ & 41.60 & 41.80 & 64.47 & 63.84 \\
\hline $\mathbf{9}$ & $\mathrm{T}_{9}\left(2^{\text {nd }}\right)$ & 43.20 & 45.20 & 65.52 & 64.05 \\
\hline $\mathbf{1 0}$ & $\mathrm{T}_{10}\left(3^{\text {rd }}\right)$ & 45.00 & 47.00 & 60.27 & 59.64 \\
\hline $\mathbf{1 1}$ & $\mathrm{T}_{11}\left(4^{\text {th }}\right)$ & 44.00 & 47.20 & 58.59 & 56.07 \\
\hline $\mathbf{1 2}$ & $\mathrm{T}_{12}\left(\mathrm{Sep} 1^{\text {st }}\right)$ & 50.40 & 49.60 & 55.23 & 53.97 \\
\hline $\mathbf{1 3}$ & $\mathrm{T}_{13}\left(2^{\text {nd }}\right)$ & 53.60 & 52.60 & 53.13 & 54.60 \\
\hline $\mathbf{1 4}$ & $\mathrm{T}_{14}\left(3^{\text {rd }}\right)$ & 54.20 & 54.40 & 49.77 & 50.61 \\
\hline $\mathbf{1 5}$ & $\mathrm{T}_{15}\left(4^{\text {th }}\right)$ & 57.80 & 59.40 & 46.20 & 45.57 \\
\hline & $\mathrm{CD}_{\text {at }} 5 \%$ & 1.027 & 1.692 & 2.552 & 2.562 \\
\hline
\end{tabular}

Note: every week made 100 layers in both the varieties.

Table.2 Effect of air layering dates (weeks) on number of secondary roots and length of longest root of air layers rooted in guava

\begin{tabular}{|l|l|c|c|c|c|}
\hline \multirow{2}{*}{ S. No. } & \multirow{2}{*}{ Weeks of layering } & \multicolumn{2}{|c|}{ Number of secondary roots } & \multicolumn{2}{|c|}{ Length of longest root (cm) } \\
\cline { 3 - 6 } & & Lalit & Shweta & Lalit & Shweta \\
\hline $\mathbf{1}$ & $\mathrm{T}_{1}\left(\right.$ June $\left.2^{\text {nd }}\right)$ & 6.40 & 5.40 & 4.64 & 4.44 \\
\hline $\mathbf{2}$ & $\mathrm{T}_{2}\left(3^{\text {rd }}\right)$ & 8.20 & 6.00 & 4.46 & 5.32 \\
\hline $\mathbf{3}$ & $\mathrm{T}_{3}\left(4^{\text {th }}\right)$ & 8.40 & 6.80 & 5.46 & 6.56 \\
\hline $\mathbf{4}$ & $\mathrm{T}_{4}\left(\mathrm{July} 1^{\text {st }}\right)$ & 10.00 & 10.20 & 5.99 & 6.26 \\
\hline $\mathbf{5}$ & $\mathrm{T}_{5}\left(2^{\text {nd }}\right)$ & 8.40 & 9.40 & 5.89 & 6.24 \\
\hline $\mathbf{6}$ & $\mathrm{T}_{6}\left(3^{\text {rd }}\right)$ & 8.40 & 8.00 & 5.93 & 5.48 \\
\hline $\mathbf{7}$ & $\mathrm{T}_{7}\left(4^{\text {th }}\right)$ & 8.80 & 7.40 & 5.26 & 5.34 \\
\hline $\mathbf{8}$ & $\mathrm{T}_{8}\left(\right.$ Aug $\left.1^{\text {st }}\right)$ & 9.00 & 7.60 & 5.50 & 6.00 \\
\hline $\mathbf{9}$ & $\mathrm{T}_{9}\left(2^{\text {nd }}\right)$ & 7.60 & 6.60 & 5.56 & 5.12 \\
\hline $\mathbf{1 0}$ & $\mathrm{T}_{10}\left(3^{\text {rd }}\right)$ & 7.40 & 6.20 & 4.88 & 4.02 \\
\hline $\mathbf{1 1}$ & $\mathrm{T}_{11}\left(4^{\text {th }}\right)$ & 5.80 & 6.80 & 4.98 & 4.82 \\
\hline $\mathbf{1 2}$ & $\mathrm{T}_{12}\left(\mathrm{Sep} 1^{\text {st }}\right)$ & 4.80 & 4.80 & 4.00 & 3.88 \\
\hline $\mathbf{1 3}$ & $\mathrm{T}_{13}\left(2^{\text {nd }}\right)$ & 5.20 & 5.20 & 4.10 & 3.64 \\
\hline $\mathbf{1 4}$ & $\mathrm{T}_{14}\left(3^{\text {rd }}\right)$ & 3.80 & 3.00 & 3.39 & 3.16 \\
\hline $\mathbf{1 5}$ & $\mathrm{T}_{15}\left(4^{\text {th }}\right)$ & 3.40 & 3.00 & 3.32 & 3.22 \\
\hline & $\mathrm{CD}_{\text {at }}$ 5\% & 0.317 & 0.320 & 1.500 & 0.217 \\
\hline
\end{tabular}

Note: After layer's detachment and during shifting in polybags counted and measured roots. 


\section{Percentage of air layers rooted}

An examination of data (Table 1) shows that the layering weeks had a significant effect on percentage of air layers rooted in the varieties Lalit and Shweta and the percentage of air layers rooted was decreased with the increasing layering dates from July $1^{\text {st }}$ week and $2^{\text {nd }}$ week in both the varieties, respectively. Maximum percentage of air layers rooted observed in Lalit variety in June $4^{\text {th }}$ week i.e. $(71.19 \%)$, while minimum percentage of air layers rooted i.e. (46.20\%) observed in September $4^{\text {th }}$ week $\left(\mathrm{T}_{15}\right)$. Variety Lalit was recorded more percentage of rooting over Shweta. In Shweta, maximum percentage of air layers rooted observed in July $2^{\text {nd }}$ week i.e. $(70.56 \%)$ and minimum percentage of air layers rooted (45.57\%) observed in September $4^{\text {th }}$ week $\left(T_{15}\right)$. The favorable climatic factors (high temperature, high humidity and averaged rainfall) prevailed at the time might be the reasons for the highest rooting success. The present finding also close finding with Sarkar and Ghosh (2006) recorded that air layers prepared during June and July showed maximum rooting success in guava. Ram and Majumdar (2000) also observed highest percentage of rooted layers $(88.5 \%)$ when layering was done in June and July in Litchi.

\section{Root character}

\section{Number of secondary roots}

The effect of weeks of layering significantly influenced on the number of secondary roots per layer of guava in both the varieties was presented in Table 2. In Lalit variety, maximum number of secondary roots observed when air layering was performed on July $1^{\text {st }}$ week i.e. (10.00) and minimum in September $4^{\text {th }}$ week i.e. (3.40). Layering time July $1^{\text {st }}$ week recorded (6.60) more secondary roots over September $4^{\text {th }}$ week $\left(\mathrm{T}_{15}\right)$. Likewise in Shweta variety, maximum number of secondary roots observed in July $1^{\text {st }}$ week i.e. (10.20) and minimum (3.00) number of secondary root jointly observed in September $3^{\text {rd }}$ and $4^{\text {th }}$ weeks.

The favorable climatic factors (high temperature, high humidity and averaged rainfall) prevailed at the time might be the reasons for the highest rooting success. The present finding also close finding with Sarkar and Ghosh (2006) recorded that air layers prepared during June and July showed maximum rooting success in guava. Ram and Majumdar (2000) also observed highest percentage of rooted layers $(88.5 \%)$ when layering was done in June and July in Litchi.

\section{Length of longest root $(\mathrm{cm})$}

It is explicit from data presented in Table 2 that significant effect on length of longest roots in both the varieties. In Lalit variety the length of longest root $(5.99 \mathrm{~cm})$ was observed maximum in July $1^{\text {st }}$ week layering time whereas minimum length of longest root (3.32 $\mathrm{cm})$ was observed in September $4^{\text {th }}$ week $\left(T_{15}\right)$. Whereas in Shweta variety the length of longest root $(6.56 \mathrm{~cm})$ observed in June $4^{\text {th }}$ week and minimum length of longest root $(3.16 \mathrm{~cm})$ observed in September $3^{\text {rd }}$ week $\left(\mathrm{T}_{14}\right)$. Similar result also reported by Rehman et al., (2013) recorded that higher root length $(5.21 \mathrm{~cm})$ was recorded when layering prepared in $15^{\text {th }}$ June in Olive. Similarly, Ram and Majumdar (2000) also recorded that highest length of roots was obtained when layering was done in June and July.

\section{References}

Bose, T.K., Mitra, S.K. and Sadhu, M.K. 1986. Guava In: Propagation of Tropical and Sub- Tropical Torticultural crops. Naya Prakash, Calcutta (W.B.), pp 291-301. 
Chundawat, B.S., Gupta, O.P. and Singh, H.K. 1976. Investigation on physiochemical qualities of rainy and winter season guava fruits. Haryana Journal of Horticultural Sciences, 5: 154-159.

Kumar, S., Sakthivel, T., Chithiraichelvan, R. and Karunakaran, G. 2007. Effect of time, media and root inducing auxins on the rooting of guava $c v$. Allahabad Safeda air layers under high rainfall zone of Kodagu. Annals of Agricultural Research, 28 (1): 10-14.

Ram, M. and Majumdar, P.K. 2000. Propagating litchi through stooling. Indian Horticulture, 25: 20-21.
Rehman, M.A., Ali, A., Khan, O. and Haq, I. 2013. Response of olive cultivars to air layering at various timings. Pakistan Journal of Agricultural Sciences, 50(4): 555-558.

Sarkar A. and Ghosh, B. 2006. Air layering in guava $c v$. L- 49 as affected by plant growth regulators, wrappers and time of operation. Environment and Ecology, 24 S (Special 3A): 820- 823.

Singh, R. 1969. In: Fruits. National Book Trust, New Delhi, pp. 89-90.

USDA data base. 2015. National nutrient data base for standard reference release, 27.

\section{How to cite this article:}

Ganesh Chand, D.K. Sarolia and Suman K. Yadav. 2018. Standardization of Dates of Guava (Psidium guajava L.) Varieties to Air Layering under Southern Rajasthan Condition. Int.J.Curr.Microbiol.App.Sci. 7(04): 1164-1168. doi: https://doi.org/10.20546/ijcmas.2018.704.128 